\title{
TRANSACTION COSTS OF ENTERPRISES: THE ISSUE OF ACCOUNTING AND ANALYSIS MANAGEMENT
}

\author{
Igor Yaremko', Tetiana Voskresenska² \\ Lviv Polytechnic National University, Ukraine
}

\begin{abstract}
Major obstacles to securing rational organization of accounting and analytical support system of the enterprise transaction costs management are examined. Organizational and methodological peculiarities of accounting and analysis of economic entities' transaction costs are defined. Characteristic aspects of official transaction cost reporting in accounting system as a part of administrative, marketing, and other operating expenses are analysed. Exclusively approximate estimate of most kinds of transaction costs is recorded. A significant impact of the amount and structure of transaction costs on the efficiency of managerial decisions regarding further enterprise activity and competitive performance is proved. Certain approaches to accounting and analytical reporting of the enterprise transaction costs are formed. The aim of the article is to investigate basic approaches to and methodological foundation of identifying, accounting, and analysis of economic entities' transaction costs, as well as their compliance with modern economic realia. The subject of the article consists of the in-depth clarification of content and economic matter of transaction costs under the conditions of modern economy; definition and generalization of chief problems in adaptive accounting of transaction costs management; justification of accounting reporting of transaction costs with due regard to peculiarities of their formalized and unofficial component reporting in accounting system. Methods of studying into theoretical and methodological background of investigation there are general scientific methods of obtaining knowledge (analysis, theoretical generalization, comparison), which were basically applied while studying approaches to the identification, as well as accounting and analytical reporting of transaction costs; methods of systematization - in establishing preconditions and challenges of accounting and analytical reporting of transaction costs; systematic approach - in determining the scheme of transaction costs origin as far as national economic subjects are concerned; statistical methods - used while analysing the rates of transaction costs. The practical significance of the work consists in the investigation of current methodological aspects of identification, as well as accounting and analytical reporting of transaction costs, in order to work out adaptive mechanisms of their pegging, accounting, and analysis under unstable economic conditions, and what is more, analysis of significance of their influence on competitive capacity of enterprises under the conditions of disequilibrium national economy. Value/originality. The originality of the work consists in the practical reinforcement of scientists' theoretical insights and formulation of improved mechanisms for the identification, accounting, and analysis of transaction costs. The theory of transaction costs introduced by R. Coase and adapted to unstable conditions of the national economic system development has been taken as a basic concept of identification, accounting and analytical reporting of enterprises' transaction costs.
\end{abstract}

Key words: accounting of transaction costs, transformational costs, official and unofficial transaction costs, identification and estimation of transaction costs, economic analysis of transaction costs.

JEL Classification: D23, D61, M41, 017

\section{Introduction}

The instability of the global economic situation has led to a shift in priorities and, as a consequence, approaches to evaluating the efficiency of enterprises. In hard-to-predict economic conditions of enterprise functioning, one of the dominant indicators of evaluating the efficiency of their activities is the value and level of incurred costs. The current practice of management by both domestic and foreign business entities and analytical reviews of the activities of wellknown world companies show that under the current unstable economic conditions, the greatest problems

Corresponding author:

${ }^{1}$ Department of Accounting and Analysis, Lviv Polytechnic National University.

E-mail: I.Yaremko@i.ua

${ }^{2}$ Department of Accounting and Analysis, Lviv Polytechnic National University.

E-mail:voskresenskat@ukr.net 
arise in the information support for sound and efficient cost management, in particular, transaction costs. At the same time, along with the difficulties associated with the formation of qualitative information support for managing the transaction costs of an enterprise, there are problems with the choice of economic tools for their accounting and analytical reflection and analysis. This is due to the incapability of most economic tools to ensure a fair matching of the expediency and efficiency of transaction costs in current activities and their projections in the formation and maintenance of a satisfactory state of long-term conditions for the development of an entity.

An important role in the study of the value, structure of transaction costs, and ensuring their proper accounting and analytical reflection is due to the fact that in the pre-crisis period, their management played a secondary role in the overall management process, which led to their unreasonable growth in certain sectors of the domestic and world economy. The lack of objective grounds for the excessive growth in the value and level of transaction costs of economic entities in practice led to a reduction in the working capital of the vast majority of both individual enterprises and countries as a whole. The shifting of the emphases of the evaluation of the enterprise efficiency through the prism of transaction costs requires the formation of adequate informational accounting and analytical support that can determine the expediency of costs, control their value, forecast the possible consequences of transaction costs incurred for the current and future activities of a company.

\section{Preconditions of transaction costs' accounting and analysis}

Volatility and variability of the world financial and economic situation caused the need to revaluate current approaches to the performance evaluation of economic entities' activity. Under such economic conditions, enterprise efficiency evaluation on the basis of the amount of earned profit or its relative index (profitability) does not make it possible to make adequate conclusions to a high degree of accuracy regarding true perspectives of the enterprise concerning defining and following the selected business line. Under dynamically unstable conditions, overall costs or their certain components are considered to be significant, complex, and one of the key appraisal objects for the assessment of enterprise activity. In the economics literature, alongside with the research into transformational costs (associated with manufacturing), scholars bring forward numerous arguments on the necessity of accounting and analysis of transaction costs (for marketing mechanism functioning) that are of major importance under the conditions of disequilibrium economy.

A closer attention to the research into transaction costs is due to dynamically uncontrolled and massive growth of their amount, which led to the expansion of world economic crisis in 2008-2018. Numerous current calculations made by foreign and national scholars have proven the influence of transaction costs on the violation of world economic stability. According to scholars' calculations (based on scientifically grounded methods) that were recorded in the economics literature, a rapid increase in the amount of transaction costs of enterprises was fixed. Generalizing information from the sources (Lemeshchenko, 2010; Kolodnyaya, 2008; Shepelenko, 2008), it should be noted that at the beginning of the XIX century, the amount of transaction costs was about 20-25\% from total expense amount and, in the XXI century, their amount in certain branches of economy is within $50-80 \%$. The more developed the economy of the country is, the lower the transaction costs are (primarily off-the-books). Enterprises operating under the conditions of disequilibrium economic system and politically-oriented economy usually bear a considerable amount of both on-therecord and off-the-books transaction costs.

\section{Applying macroeconomic indices to predict the level of transaction costs}

Having studied the value of certain macroeconomic indices, it is possible to define the trends of transaction costs quite clearly, though in some ways indirectly, on macro- and micro- levels. For such purposes, it is suggested using and analysing the value of the Ease of Doing Business Index considering its structural and indicative components. This index is calculated and published annuallyin the appropriate report by the World Bank. Using the information on value and dynamics of this index, it is possible to characterize variations of transaction costs in view of different countries taking into consideration their rating defined on the basis of Ease of Doing Business Index. Studying the declared values of aggregative indicative components of the Ease of Doing Business Index (business registration, obtaining building permission, connection to energysaving systems, property registration, receiving a loan, protection of minority investors' rights, taxation, international trade, contract performance security, solution to insolvency problems) in dynamics (Table 1 ), it can be noted that there is a moderate decrease in transaction costs, which shows the growth of index value within the country.

The above-noted approach to trend analysis of changes in transaction costs is rather simplified because in the process of calculating the Ease of Doing Business Index, only a small number of factors, which have a great influence on the amount of transaction costs, is taken into consideration. At the same time, such factors as level of corruption in the country, infrastructure quality, exchange rate change, level of politicization 
Table 1

Macroeconomic indices for determining trends of changes in the general level of transaction costs in Ukraine

\begin{tabular}{|l|c|c|c|c|c|l|}
\hline \multicolumn{1}{|c|}{ Index } & 2012 & 2013 & 2014 & 2015 & 2016 & \multicolumn{1}{|c|}{ Note } \\
\hline $\begin{array}{l}\text { Ease of Doing Business Index } \\
(0-100)^{* *} 189 \text { countries }\end{array}$ & $\begin{array}{c}44,27 \\
(152)\end{array}$ & $\begin{array}{c}48,87 \\
(137)\end{array}$ & $\begin{array}{c}58,64 \\
(112)\end{array}$ & $\begin{array}{c}61,72 \\
(96)\end{array}$ & $62,90(83)$ & $\begin{array}{l}\text { The lower the value is, the better, the } \\
\text { fewer obstacles to doing business }\end{array}$ \\
\hline $\begin{array}{l}\text { Corruption Perception Index } \\
(0-100)^{* *}\end{array}$ & 26 & 25 & 26 & 27 & 29 & $\begin{array}{l}\text { The closer the index value to } 100 \text { is, } \\
\text { the higher the country rating is }\end{array}$ \\
\hline Level of shadow economy*** & $34 \% \mathrm{GDP}$ & $35 \% \mathrm{GDP}$ & $40 \% \mathrm{GDP}$ & $43 \% \mathrm{GDP}$ & $41 \% \mathrm{GDP}$ & $\begin{array}{l}\text { Positive meaning of the decrease in } \\
\text { the share of the shadow economy in } \\
\text { GDP }\end{array}$ \\
\hline
\end{tabular}

*the source of information is the website of the World Bank

**the source of information is the website Transparency International

*** the source of information is the website of the Ministry of Economic Development and Trade of Ukraine

of the economy and dependence on international credits/subsidies are not taken into consideration while calculating the Ease of Doing Business Index though it is advisable to consider these factors while analysing the level of transaction costs. However, in order to somehow compensate for inaccuracies (or to prove its reliability) of analysis of transaction costs level (low, average, high) carried out using the Ease of Doing Business Index, the analysis may be supplemented with such informative indices as the perception of corruption and the level of shadow economy (Table 1). If the Ease of Doing Business Index was determined for certain branches of the country's economy, conclusions concerning the dynamics of transaction costs would be more accurate. This is due to the fact that the amount, constituents, and structure of transaction costs are different in various economic realms depending on the branch specificity. Some branches need various kinds of permissions and agreements for their current performance (for example, building industry, machinery manufacturing, etc.) so the amount of transaction costs at such enterprises will be larger in comparison with the enterprises that do not need a special permission documentation for their activity.

Having analysed the information in Table 1, it may be noted that the level of transaction costs in Ukraine is high as indicated by the Level of Shadow Economy and Corruption Perception Index value. Growth dynamics of the level of shadow economy may prove the increase in the amount of an unofficial part of transaction costs. Thus, generalized analysis of the above-mentioned macroeconomic indices attests persistently high level of transaction costs in certain branches of domestic economy. The specified macroeconomic indices recommended for determining the level of transaction costs may be also used to carry out a comparative analysis of such costs level in various countries of the world, hence setting the trends for changes of macrolevel transaction costs in one or another country.

Scholars pay more attention to the study of transaction costs because such costs are hard to predict, their value growth is uncontrolled, and due to prevailing negative influence on the competitive performance of enterprise activity. Thus, optimization, usually by means of transaction costs minimization, is one of the crucial tasks of enterprises and governments. "It is clear that zero transaction costs are theoretical abstraction rather than reality description ..., practical goal of economic policy should be to minimize transaction costs to the extent possible and not to entirely abolish them" (Vítek, 1998).

\section{Analysis of the latest studies on identification, accounting, and analytical reporting of transaction costs}

In the economics literature, there are numerous theoretical and application-oriented publications regarding the definition and accounting of transaction costs. In certain academic papers, scholars pay a particular attention to the investigation of ontological aspects of transaction costs' definition, formation and generalization of transaction costs classification, the practicability of reporting such costs in the enterprise accounting system. R. Coase (1993) was the first who officially claimed the presence of transaction costs in the economic system, highlighting their significant influence on the enterprise. H.V. Kolodnaia (2008) conducted a comprehensive study of the analysis of transaction costs' role in the course of enterprise development. O.V. Shepelenko (2008) in her work analysed the theoretical and methodological background and set forward practical guidelines for transaction costs management designed to secure economic growth in Ukraine. Among other things, the author built up a concept of transaction costs controlling mechanism in the Ukrainian economy founded on institutional approach and principles of system development (Shepelenko, 2008). N.V. Hordopolova, V.Y. Hordopolov (10) disclosed prerequisites and sources of transaction costs origin, mechanism of their origin, study procedures, and information support of such procedures. M.V. Verhunenko (2008) analysed the level of transaction costs in the business sector of Ukraine in comparison with member countries of the European Union and defined trends of their change, as well as obstacles to the integration of Ukraine into 
the world economy. T.I. Kurylo, T.M. Sliozko (2016) studied the notion of transaction costs in relation to institutes and institutions in an institutional environment, as well as peculiarities of their formation in the agricultural sector. The influence of institutional environment sector on transaction costs formation was defined. O.M. Halytskyi (2013) set forward an approximate estimation procedure algorithm of transaction costs associated with agricultural goods sales. The algorithm is based both on accounting and reporting data usage and determining foregone earnings in order to estimate implicit transaction costs.

\section{Approaches to the identification, accounting, and analytical reporting of transaction costs; their adaptation to disequilibrium economic conditions}

Taking into consideration an upward trend of transaction costs, it is worth mentioning that the necessity of their accounting and analysis is caused by determining the influence of transaction costs on competitive performance of certain enterprises, as well as states or their unions. Despite the urgent need of enterprises caused by current unstable economic realia to form accounting and analytical security of transaction costs. Here are the main obstacles to rational organization of accounting and analysis of transaction costs, provided in the economics literature (Lukichev, 2010; Verhunenko, 2011):

- theoretical and methodological disagreements over the determination of subject-matter of transaction costs; - lack of efficient legal leverages over individual elements and the total amount of transaction costs;
- lack of detailed and reasoned classification of transaction costs because of their interrelation and complementarity with transformational costs;

- the necessity for the development of efficient approaches to the identification and estimation procedure of transaction costs on macro- and microlevels;

- indefinite (implicit) nature of certain types of transaction costs (lack of documenting of most of them);

- time-based delimination of origin of certain transaction costs components;

- the considerable proximity of transaction costs estimation, applying procedures suggested in the academic literature.

Given the fact that transaction costs largely influence financial, economic, and business activity of enterprises, it is appropriate to determine peculiarities of their origin with due account for the nature of transaction costs. A simplified scheme of transaction costs origin in the process of economic entities' cooperation is depicted in Fig. 1.

Fig. 1 shows that transaction costs arise between enterprises when they are making agreements on cooperation (1). In particular, transaction costs arise before the conclusion of the agreement and they are connected with the search for clients, negotiations, and alignment of interests.

Another part of transaction costs (2) arises when the agreement obligations between the parties are being fulfilled. These are costs associated with the control over fulfilment of the contract items, their alterations (adaptations) when there are changes in the market or in its particular segment. Besides, transaction costs

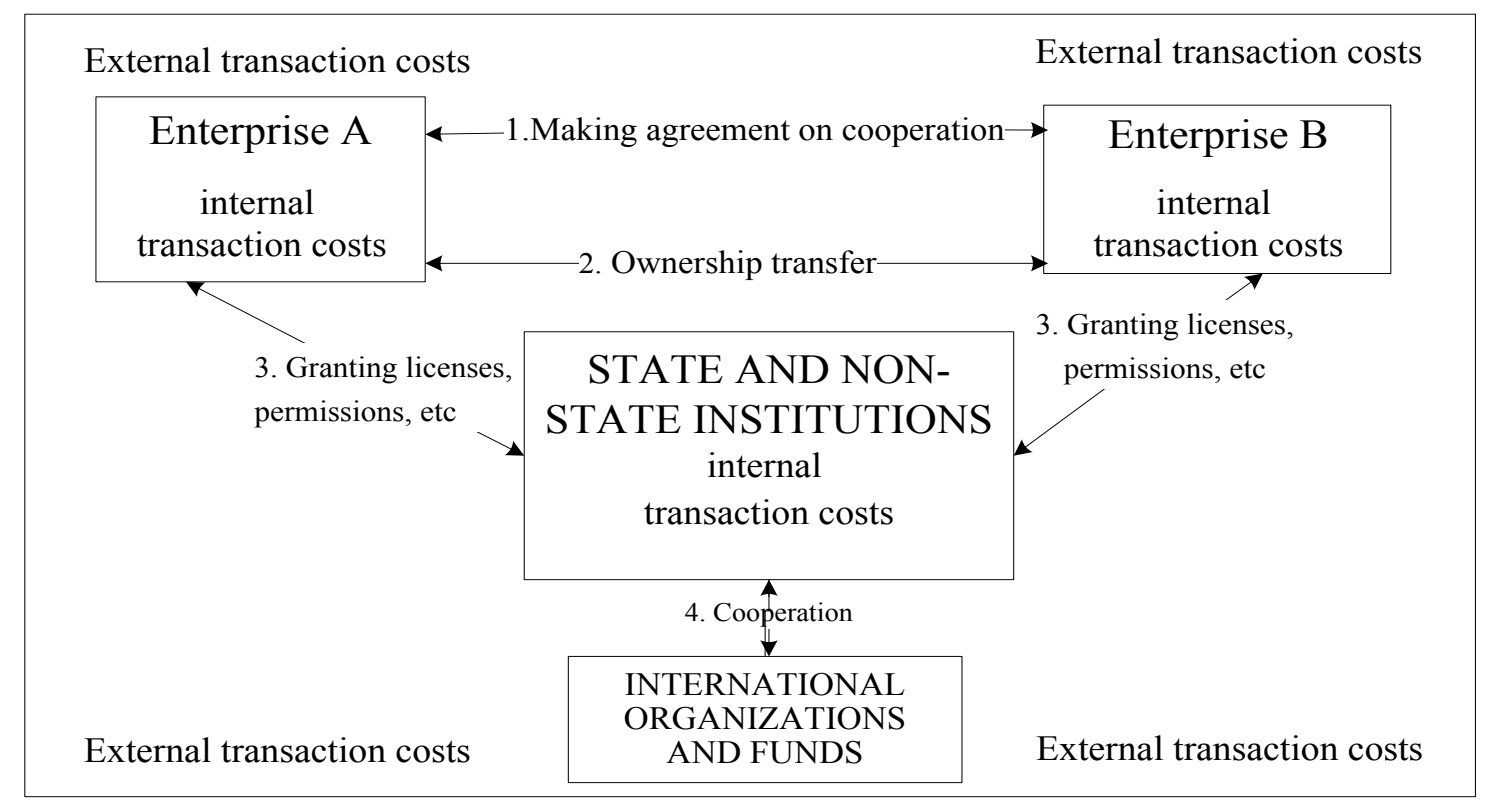

Fig. 1. A simplified scheme of transaction costs origin within domestic economic entities 
associated with enterprise management and activity (3) arise in the process of its cooperation with state (fiscal service, government, deputy corps, customs, judicial authorities) and non-state (insurance company, notary office, and bank) institutions in the process of obtaining permissions for a certain activity, tax payment and non-tax payment, customs clearance of goods, etc. Transaction costs arising in the process of interaction between enterprises are microlevel costs having an impact on the activity of any given enterprise. Macrolevel transaction costs arising in the process of cooperation with international organizations and funds (4) are associated mainly with getting a loan or financial aid. They are defining for certain states. In the process of such cooperation, governments of countries implement the requirements they had in order to develop a closer cooperation with international organizations and funds and meet the requirements.

In Fig. 1, it is noted that transaction costs may have internal and external forms of manifestation. Internal transaction costs may arise in the process of cooperation between shareholders (minority and majority), shareholders (owners) and enterprise management, enterprise and its employees. External transaction costs go beyond the enterprise and arise in the process of their cooperation with the other parties of the economic system.

Range of problems associated with accounting and analysis management of transaction costs is caused by lack of structured informational background concerning their amount, level, and structure; certain components of transaction costs are reported as administrative costs (representational expenses, travel expenses, acquisition of licenses), marketing expenses (advertising costs, warranty repairs), other operating costs, financial and investment costs. Separate mapping of transaction costs on individual accounts for operating costs accounting leads to underestimation of their overall impact on the economic entity performance (expenses, prime cost, profit, competitive capacity). Apart from that, only on-the-record part of transaction costs is reflected in accounting system while "off-the-books costs connected with overcoming bureaucratic barriers remain out of accounting records, constitute enterprise's commercial secret and, in some cases, they may significantly outweigh on-the-record part" (Verhunenko, 2011). While on-therecord transaction costs are mapped in the accounting system, off-the-books costs can be usually estimated approximately applying heuristic methods (expert) or cannot be estimated at all due to the lack of evidence or facts of their realization. Enterprise management or owners often do not disclose information on the amount of off-the-books transaction costs because they are usually illegal so it makes sense to report such transaction costs in the system of managerial accounting.

\section{Analysis of transaction costs dynamics as exemplified by machine-building enterprises}

In order to determine the trends of changes of the transaction costs amount as far as domestic economic entities are concerned, let us make their analysis (using on-the-record financial accounting) as exemplified by machine-building enterprises (Table 2).

The amount of on-the-record transaction costs is provided in Table 2. The information on the trends of

Table 2

Trend data to analyse transaction costs of machine-building enterprises over a period of 2012-2016

\begin{tabular}{|c|c|c|c|c|c|}
\hline Criteria, thousands hryvnias. & 2012 & 2013 & 2014 & 2015 & 2016 \\
\hline \multicolumn{6}{|c|}{ PJSC "Conveyer" } \\
\hline Transaction costs as a part of operating expenses, thousands hryvnias & 16320 & 6519 & 6614 & 7848 & 8734 \\
\hline The amount of transaction costs (prime cost), $\%$ & 123,17 & 53,83 & 49,69 & 55,64 & 46,78 \\
\hline The amount of transaction costs (net profit), \% & 109,71 & 50,30 & 45,11 & 48,52 & 39,32 \\
\hline \multicolumn{6}{|c|}{ PJSC "Korosten Machine Building Plant" } \\
\hline Transaction costs as a part of operating expenses, thousands hryvnias & 3246 & 2927 & 3748 & 3261 & 2948 \\
\hline The amount of transaction costs (prime cost), $\%$ & 19,27 & 18,96 & 31,72 & 24,49 & 20,80 \\
\hline The amount of transaction costs (net profit), \% & 16,49 & 16,82 & 33,89 & 23,92 & 20,44 \\
\hline \multicolumn{6}{|c|}{ PJSC "Beryslav Machine Building Plant" } \\
\hline Transaction costs as a part of operating expenses, thousands hryvnias & 15070 & 13055 & 42374 & 65543 & 46318 \\
\hline The amount of transaction costs (prime cost), $\%$ & 17,24 & 14,53 & 47,36 & 140,58 & 52,04 \\
\hline The amount of transaction costs (net profit), \% & 15,13 & 13,20 & 43,59 & 134,25 & 47,58 \\
\hline \multicolumn{6}{|c|}{ PJSC "Odesa Machine Building Plant" } \\
\hline Transaction costs as a part of operating expenses, thousands hryvnias & 29238 & 9466 & 11231 & 12990 & 16711 \\
\hline The amount of transaction costs (prime cost), \% & 174,43 & 66,01 & 86,03 & 66,30 & 59,69 \\
\hline The amount of transaction costs (net profit), \% & 134,22 & 66,34 & 79,88 & 72,07 & 48,85 \\
\hline \multicolumn{6}{|c|}{ PJSC "Drohobych Machine Building Plant” } \\
\hline Transaction costs as a part of operating expenses, thousands hryvnias & 4636 & 4796 & 7199 & 5433 & 5010 \\
\hline The amount of transaction costs (prime cost), \% & 37,43 & 67,44 & 82,44 & 96,67 & 54,30 \\
\hline The amount of transaction costs (net profit), $\%$ & 24,39 & 45,41 & 62,37 & 95,62 & 41,18 \\
\hline
\end{tabular}


transaction costs is presented in Table 2 and it shows that transaction costs trend upward in a majority of enterprises under investigation as far as absolute value, prime cost, and net profit are concerned. Although the enterprises under investigation belong to the same branch, the amount of transaction costs as a part of their profit differs, due to specific operational peculiarities. As far as enterprises under investigation are concerned, an average value of transaction costs within these enterprises ranges from 20 to $80 \%$ in profit value. There is a need in their systematization and analysis because the on-the-record value of transaction costs influences final financial results of the enterprise activity.

N.V. Hordopolova, V.Y. Hordopolov (2010) emphasize the necessity of well-ordered and constant accounting of transaction costs, "separating transaction costs in accounting and their analysis are necessary because such costs are scattered among various business and support units of the enterprise and their amount remains unknown for the managerial apparatus though their product costs in high-tech spheres may reach $20 \%$ and more". That is why systematization of information on transaction costs and their detailed list are gaining significant importance as it allows adjusting the value of certain components of transaction costs in current mode helping to reduce the total value of transaction costs. The problem of measuring transaction costs lies in the fact that it is not always possible to determine their amount and rate their dynamics. Only the on-therecord constituent of transaction costs is subject to quantitative measurement of transaction costs, while off-the-books constituent is practically impossible to measure as a part of the traditional accounting system. Under such conditions, off-the-record transaction costs are measured applying qualitative methods establishing the direction of their change or determining the influence (positive, negative) on enterprise performance efficiency. At the same time, it should be pointed out that "nowadays there is no universal, worked out, quantitative method of transaction costs accounting, which is caused by difficulties in accounting and estimation of certain transaction costs categories, as well as a considerable amount of their classifications and definitions" (Halytskyi, 2013). Thus, in the process of accounting management, there are good reasons to group transaction costs typologically in view of certain transactions (exchange, administration, rationing, etc.) with the further specification, when transaction costs may arise, be modified and integrated into other types of enterprise expenses. Information on transaction costs grouped in such a manner will be used for their estimation and analysis.

Such scholars as P.S. Lemeshchenko (2011) and H.V. Kolodnia (2008) emphasize in their works that transaction costs are irrational, noting that "the general conclusion that can be made on the basis of transaction costs theory is that division of labour and exchange transactions, on which economic activity is based within market model, lead to huge and irrational in terms of social usefulness expenses" (Lemeshchenko, 2011). Transaction costs have become the key factor of the enterprise natural selection, signalling the necessity for changes of organizational structure in order to ensure company's strong position on the market (Kolodnia, 2008). In other words, transaction costs may be considered to be a kind of indicator of the necessity for changes in the enterprises' inner structure, forms and methods of their cooperation with counterparts, directions of their activity, market segments, etc.

Conclusions concerning totalvalue of transaction costs regulation, the structure of their certain constituents and dynamics depend on the quality of accounting and analytical analysis of transaction costs. This is due to the fact that in order to conduct the analysis of transaction costs accounting records are used (70-80\% out of all the information), and they do not fully reflect composition and structure of transaction costs and so "the problem of determining their composition still remains unsolved because of a large share of irregular, specific, uncontrolled expenses of probable or expected nature. This is the reason why it is impossible to gather information on their actual state within accounting system that deals with carried out business operation facts" (Kurylo, Slozko, 2016). Thus, a major part of transaction costs, basically associated with corruption element, cannot be measured directly. Consequently, the first priority goal of financial and economic services is to manage accounting procedures of transaction costs because accounting is a basic informational framework for the analysis and evaluation of transaction costs with a view to making management decisions concerning further enterprise performance. While using the information obtained in the process of transaction costs analysis, economic entities may need to manage and keep records of certain transaction costs constituents that have not been reflected in this information system.

Necessity for accounting and analysing transaction costs is conditioned by the need of their minimization, and more precisely, optimization that requires qualitative information support, with the help of which it is possible to determine rational structure of transaction costs, predict their further dynamics, define macroand micro- economic factors of enterprise transaction costs' changes. Given the fact that transaction costs result from the interaction between certain economic entities, between enterprises and public institutions, informational transparency of transactions is the basic and important factor of their optimization.

\section{Conclusion}

Therefore, while managing accounting and analysis of transaction costs, it should be considered that their certain types may be of probable nature and for this 
reason they cannot be reflected in the traditional accounting system. Efficient accounting of transaction costs allows making efficient decisions on optimization of their value and structure, as well as gives an opportunity to influence their dynamics in a certain way. Alongside with that, it should be pointed out that management of transaction costs accounting and analysis becomes difficult on account of certain factors associated with transaction costs origin and increase: constant increase in the number of transactions; overwhelming globalization of economic processes, their dynamism and the fact that they are hard-topredict; politicization of economic systems of countries, their unions and global economic system; asymmetry of information.

Based on the results of the research conducted, it may be noted that basic suggestions of scholars regarding management of transaction costs accounting may be confined to the introduction of a separate account or a system of sub-accounts to expenditure accounts of operating activity. However, scholars' advisory suggestions do not solve the problem of the rational organization of accounting and reduction of off-the-record transaction costs of enterprises without documentary evidence, calling for the use of alternative accounting system for their recording and control.

The dynamism of economic systems at the level of both enterprise and state has shifted managerial accents of company's management from increase in profits to optimization of costs, and primarily transaction costs that have an overwhelming influence on the competitive capacity of an enterprise and in most cases on ensuring sufficient conditions of their existence and development. Information support, which is mainly formed within accounting system, is essential for the purpose of developing efficient managerial mechanisms for transaction costs. However, taking into consideration the existence of on-the-record and offthe-books constituents of transaction costs, qualitative information support necessary for management and control may be formed only when information from both bookkeeping and managerial accounting is used, which is the direction for further investigation.

\section{References:}

Halytskyi O.M. (2013) Orhanizatsiino-ekonomichni pidkhody do obliku ta otsinky transaktsiinykh vytrat u silskohospodarskykh pidpryyemstvakh [Organizational and economic approaches to accounting and evaluation of transaction costs in agricultural enterprises], pp. 14-28. (in Ukrainian)

Hordopolova N.V., Hordopolov V.Y. (2010) Oblikovo-analitychne zabezpechennia upravlinnia transaktsiinymy vytratamy [Accounting and analytical support for managing transaction costs]. Bulletin of ZhDTU, no 4(54), pp. 62-64. (in Ukrainian)

Kolodnyaya G.V. (2008) Transaktsionnye izderzhki kak faktor evolyutsii firmy [Transaction costs as a factor in the evolution of the firm] (PhD Tesis), Moskva, 43 p. (in Russian)

Kouz R. (1993) Priroda firmy [Nature of the firm]. Moscow: Delo, pp. 192. (in Russian)

Kurylo T.I., Slozko T.M. (2016) Transaktsiini vytraty v instytutsionalnomu seredovyshchi ahrarnoho sektoru ekonomiky [Transaction costs in the institutional environment of the agrarian sector of the economy]. Ekonomichni studii, no 2 (10), pp. 71-75. (in Ukrainian).

Lemeshchenko P.S. (2010) Institutsionalno-evolyutsionnaya teoriya novoy ekonomicheskoy reform [Institutionalevolutionary theory of new economic reforms.]. Ekonomicheskie nauki Vestnik Nizhegorodskogo universiteta im. N.I. Lobachevskogo, no 3 (2), pp. 619-624. (in Russian)

Lukichev M.Y. (2011) Upravlenie transaktsionnymi izderzhkami stroitelnykh korporatsiy [Management of transaction costs of building corporations] (PhD Tesis), Moscow. - 23 p. (in Russian)

Ofitsiinyi sait Ministerstva ekonomichnoho rozvytku i torhivli Ukrainy. Retrieved from: http://www.me.gov.ua/ Documents / List?lang=uk-UA\&id=e384c5a7-6533-4ab6-b56f-50e5243eb15a\&tag=TendentsiiTinovoi Ekonomiki.

Ofitsiinyi sait Transparency international. Retrieved from: http://www. transparency.org/cpi2015\#results-tableOfitsiinyi sait World Bank. Retrieved from: http://www.doingbusiness.org/Custom-Query

Shepelenko O.V. (2008) Upravlinnia transaktsiinymy vytratamy v ekonomitsi Ukrainy [Management of transactional costs in the economy of Ukraine]. (PhD Tesis), Donetsk, 35 p. (in Ukrainian)

Verhunenko M.V. (2008) Analiz transaktsiinykh vytrat rehuliatornykh vytrat v konteksti intehratsii Ukrainy v svitovu ekonomiku [Analysis of transaction costs of regulatory expenditures in the context of Ukraine's integration into the world economy]. Naukovi pratsi DonNTU. Seriia ekonomichna. Vol. 33, no 2, pp. 232-239. (in Ukrainian) Vítek L. (1998) Ronald H. Coase: Společenské náklady, teorie externalit a jejich řešení. In Externality a možnosti jejich řešení: Sborník referátů $\mathrm{z}$ teoretického semináře. [H. Coase: Social costs, theory of externalities and their solutions. In Externality and Possibilities of Their Solutions: Proceedings of the Theoretical Seminar]. Katedra veřejné ekonomie. Masarykova univerzita. Brno. 